\title{
Editorial
}

\section{The mysterious steps in carcinogenesis}

\author{
D Brash ${ }^{*, 1}$ and J Cairns ${ }^{*, 2,3}$ \\ 'Yale Comprehensive Cancer Center, Yale School of Medicine, New Haven, CT 06520-8040, USA; ${ }^{2}$ Clinical Trial Service Unit, University of Oxford, Oxford \\ OX3 7LF, UK; ${ }^{3} 105$ Alleyn Park, London SE2I 8AA, UK
}

British Journal of Cancer (2009) I 0 I, 379 - 380. doi: I0.1038/sj.bjc.6605 I7I www.bjcancer.com (c) 2009 Cancer Research UK

The mutational changes needed to create a cancer cell have been itemised in great detail (Hahn and Weinberg, 2002). These mutations are commonly assumed to accumulate over the course of years as a consequence of spontaneous replication errors or, in special cases, the misrepair of DNA lesions introduced by carcinogens such as tobacco smoke or sunlight. Yet, there are numerous discrepancies between the mutagenicity of chemicals and their danger to humans (Clemmesen and Hjalgrim, 1977; Jansen et al, 1980; Ames et al, 1987), and the time course of carcinogenesis is deeply mysterious. Indeed, we still do not know the proximate causes of most cancers even though these are what we want to learn how to avoid.

The classical method for creating cancers, in rabbits (Friedewald and Rous, 1944) in mice (Berenblum and Shubik, 1947) and perhaps in humans (Pott, 1775), by applying coal tar to the skin, involves a sequence of steps, called initiation and promotion (Friedewald and Rous, 1944), which bear no obvious relation to what is now known about the molecular biology of cancer. For example, a mouse can be 'initiated' by feeding it once with $1 \mathrm{mg}$ of the coal tar derivative 9,10-dimethyl-1,2-benzanthracene (Boutwell, 1964). This single treatment with a mutagen apparently causes cells to undergo a permanent change so that, for the rest of the mouse's life, its skin has become susceptible to the production of papillomas and carcinomas on exposure to the non-mutagenic irritants in croton oil. Surprisingly, a similar sequence has been seen using cells in vitro, where brief exposure to $\mathrm{X}$-rays or methylcholanthrene apparently produces a permanent change in every cell so that, many generations later, its descendants occasionally undergo 'spontaneous' transformation into cancer cells (Kennedy et al, 1980, 1984). Why does there have to be a long interval between a cell's exposure to a mutagen and the expression of the resulting mutations, and why do only a minority of the cell's descendants express these mutations?

It would have been tempting to postulate that the various methods for producing cancer in the cells of animals are not good models of human carcinogenesis, were it not for the fact that humans and animals show the same strange relationship between dose of carcinogen and time of appearance of their cancers. For example, although the incidence of lung cancer in smokers appears to be directly proportional to the number of cigarettes smoked per day (Zaridze and Peto, 1986), it is proportional to roughly the sixth power of the duration of smoking. Similarly, when rats are

\footnotetext{
*Correspondence: D Brash; E-mail: douglas.brash@yale.edu or John Cairns; Email: j.cairns@ctsu.ox.ac.uk
}

continuously exposed to dietary carcinogens, their incidence of cancer rises as the first or second power of the dose rate but as a much higher power of time (Druckrey, 1967; Peto et al, 1997). If the carcinogen had simply to mutate a set of $\mathrm{N}$ genes to create cancer, the frequency of cancer should rise as the $\mathrm{Nth}$ power of the dose, and time would not be a major factor. These numerous experiments suggest, therefore, that mutagenic carcinogens cause just one or two events and that these (similar to the initial event in in vitro carcinogenesis) are then followed by steps that accumulate solely with the passage of time, driven perhaps by cell division. Thus, the rabbit whose ears have been painted with coal tar tends to develop its skin cancers where, months later, samples of its skin were excised and therefore had to be replaced by extra division in the surrounding epithelium (Linell, 1947). To take two well-documented examples of carcinogenesis in humans, a chimney sweep did not get scrotal cancer until after puberty when he had grown too large to climb chimneys (Pott, 1775); and smokers keep their raised rate of lung cancer for many years after they have stopped smoking (Halpern et al, 1993).

To recapitulate, there are examples where the sequence changes found in cancer cells are the type known to be produced by the initiating carcinogen (Brash et al, 1991; Hsu et al, 1991; Hainaut and Pfeifer, 2001), but the study of cancer in humans and animals, overall, has produced a very confused picture. The techniques of modern molecular biology have documented the many defects of cancer cells, so there is by now a fairly clear understanding of the basis for the dangerous properties of cancer cells. However, the picture that emerges from the classical studies of the epidemiology of human cancers and of experimental carcinogenesis in animals is hard to reconcile with what has been learnt about mutagenesis in simple systems such as the bacteria. Initiation seems to be far too efficient to be simply mutagenesis of certain oncogenes and suppressor genes, and the subsequent time-dependent steps are even more obscure.

In recent years, it has become plain that the management of biological information involves several unexpected mechanisms that limit the consequences when nucleic acids and proteins are damaged. Interactions between cells can protect against their individual defects (Rubin, 2006) and, on a larger scale, the expansion of abnormal clones can be inhibited by their normal neighbours (Chao et al, 2008). Within each individual cell, there is a large set of 'heat-shock proteins' (HSPs) that manages the folding and operation of the products of gene expression, and one of the actions of these HSPs is to sequester or remove the abnormal proteins produced as the result of mutation or chance misfolding. After exposure to harsh environmental conditions such as a 
sudden rise in temperature, the pattern of synthesis of the various HSPs is altered, and the inactivation of one of the many HSP genes has been shown to result in the expression of previously hidden mutations, suggesting that one function of HSPs is to allow complex evolutionary steps to occur under conditions of stress even when the changes entail a combination of several individually disadvantageous steps (Rutherford and Lindquist, 1998). Keeping those mutations masked may contribute to tumorigenesis, because inactivation of one of the HSP genes has been found to lower the frequency of skin cancer in mice exposed to initiation by dimethylbenzanthracene and promotion by phorbol esters (Dai et al, 2007).

The prime mystery in carcinogenesis remains the very first step, because it is hard to imagine how the numerous genetic changes found in cancer cells could have been produced in any cell as the result of a single exposure to a DNA-damaging agent, or why months or years should have to elapse before the effect of these changes is observed. Past speculations about the process of carcinogenesis (as opposed to the characteristics of the end product) have had little popularity and negligible impact. Indeed, the early suggestions that cancer cells owe their properties to mutation (Tyzzer, 1916) and that carcinogens interact with DNA (Boyland, 1952) were, in their time, violently attacked (Miller and Miller, 1952; Rous, 1959). Now, perhaps with all these recent discoveries of additional mechanisms that protect cells from damage, it may soon be possible to produce a plausible model for what is going on during carcinogenesis. At least one new idea seems to be needed, and the main purpose of this article is to alert readers to new developments that could at last start to clarify what is going on during carcinogenesis.

\section{REFERENCES}

Ames BN, Magaw R, Gold LS (1987) Ranking possible carcinogenic hazards. Science 236: $271-280$

Berenblum I, Shubik P (1947) The role of croton oil applications, associated with a single painting of a carcinogen, in tumour induction of the mouse's skin. Br J Cancer 1: 383-391

Boyland E (1952) Different types of carcinogens and their possible modes of action. A review. Cancer Res 12: 77-84

Boutwell RK (1964) Some biological aspects of skin carcinogenesis. Prog Exp Tumor Res 4: 207-250

Brash DE, Rudolph JA, Simon JA, Lin A, McKenna GJ, Baden HP, Halperin AJ, Pontén J (1991) A role for sunlight in skin cancer: UV-induced p53 mutations in squamous cell carcinoma. Proc Natl Acad Sci USA 88: $10124-10128$

Chao DL, Eck JT, Brash DE, Maley CC, Luebeck EG (2008) Pre-neoplastic lesion growth driven by the death of adjacent normal stem cells. Proc Natl Acad Sci USA 105: 15034-15039

Clemmesen J, Hjalgrim S (1977) On the absence of carcinogenicity to man of phenobarbital. Acta Pathol Microbiol Scandinav Suppl 261: $38-50$

Dai C, Whitesell L, Rogers AB, Lindquist S (2007) Heat shock factor 1 is a powerful multifaceted modifier of carcinogenesis. Cell 130: 1005-1018

Druckrey H (1967) Quantitative aspects in chemical carcinogenesis. UICC Monogr Ser 7: $61-79$

Friedewald WF, Rous P (1944) The initiating and promoting elements in tumor production. J Exp Med 80: $101-126$

Hahn WC, Weinberg RA (2002) Rules for making human tumor cells. $N$ Engl J Med 347: 1593 - 1603

Hainaut P, Pfeifer GP (2001) Patterns of p53 G $\rightarrow \mathrm{T}$ transversions in lung cancers reflect the primary mutagenic signature of DNA-damage by tobacco smoke. Carcinogenesis 22: 367-374

Halpern MT, Gillespie BW, Warner KE (1993) Patterns of absolute risk of lug cancer mortality in former smokers. J Natl Cancer Inst 85: $457-464$
Hsu IC, Metcalf RA, Sun T, Welsh JA, Wang NJ, Harris CC (1991) Mutational hotspot in the p53 gene in human hepatocellular carcinomas. Nature 350: $427-428$

Jansen JB, Clemmesen J, Sandaram K (1980) Isoniazid - an attempt at retrospective prediction. Mutat Res 76: $85-112$

Kennedy AR, Fox M, Murphy G, Little JB (1980) Relationship between Xray exposure and malignant transformation in C3H $10 \mathrm{~T} \frac{1}{2}$ cells. Proc Natl Acad Sci 77: $7262-7266$

Kennedy AR, Cairns J, Little JB (1984) Timing of the steps in transformation of $\mathrm{C} 3 \mathrm{H} 10 \mathrm{~T} \frac{1}{2}$ cells by X-irradiation. Nature 307: $85-86$

Linell E (1947) On the tumour promoting effect of a single mechanical trauma. Acta Path Microbiol, Scandinav 71(Suppl): 1-110

Miller EC, Miller JA (1952) In vivo combinations between carcinogens and tissue components and their possible role in carcinogenesis. Cancer Res 12: $547-556$

Peto R, Gray R, Brantom P, Grasso P (1997) Dose and time relationships for tumor induction in the liver and esophagus of 4080 inbred rats by chronic ingestion of $\mathrm{N}$-nitrosodiethylamine or $\mathrm{N}$-nitrosodimethylamine. Cancer Res 51: $6452-6469$

Pott P (1775) Chirurgical observations relative to the cataract, the polypus of the nose, the cancer of the scrotum, the different kinds of ruptures, and the mortification of the toes and feet. (Reprinted in Natl Cancer Inst Monogr 10: 7-13; 1963)

Rous P (1959) Surmise and fact on the nature of cancer. Nature 183: $1357-1363$

Rubin H (2006) What keeps cells in tissues behaving normally in the face of myriad mutations? BioEssays 28: 515-524

Rutherford SL, Lindquist S (1998) Hsp90 as a capacitator for morphological evolution. Nature 396: $336-342$

Tyzzer EE (1916) Tumour immunology. J Cancer Res 1: 125-155

Zaridze D, Peto R (eds) (1986) Influence of dose and duration of smoking on lung cancer rates. In Tobacco: Major international health hazard, Vol 7423 -33. IARC Sci. Publs: Lyon 